\title{
Kypsennetty ohra pikkuvasikoiden ruokinnassa
}

\author{
Arto Huuskonen ${ }^{1)}$ ja Susanna Jansson ${ }^{2)}$ \\ ${ }^{1)}$ Maa- ja elintarviketalouden tutkimuskeskus, Kotieläintuotannon tutkimus, Halolantie 31A, 71750 \\ Maaninka,arto.huuskonen@mtt.fi \\ ${ }^{2)}$ Haapajärven ammattiopisto, Erkkiläntie 1,85800 Haapajärvi, susanna.jansson@cop.fi
}

\section{Tiivistelmä}

Viljan prosessoinnilla pyritään muun muassa parantamaan rehun sulavuutta. Ohraa voidaan prosessoida veden ja lämmön avulla siten, että ohran sisältämät tärkkelysjyväset turpoavat ja tärkkelys liisteröityy. Tässä raportoitavalla kokeella haluttiin selvittää ohran kypsentämisen vaikutus pikkuvasikoiden kasvuun ja rehun syöntiin juottokauden aikana.

Koe toteutettiin MTT:n Ruukin toimipisteessa. Koevasikat (12 kpl maitorotuisia sonnivasikoita) kerättiin paikallisilta lypsykarjatiloilta ternivasikoina (eläinten ikä 1-2 viikkoa). Juottokoe alkoi syyskuussa 2005 ja päättyi marraskuussa 2005. Vasikat arvottiin välittömästi MTT:lle tulon jälkeen täysin satunnaisesti kahteen ruokintaryhmään. Molempiin ruokintaryhmiin tuli tällöin 6 vasikkaa. Eläimet sijoitettiin kokeen ajaksi yksilökarsinoihin $(120 \mathrm{~cm} * 120 \mathrm{~cm})$, joissa rehujen syönti mitattiin yksilöllisesti päivittäin. Ensimmäinen koeryhmä sai vapaasti väkirehuseosta, jossa oli kypsentämätöntä litistettyä ohraa (75\%), rypsipuristetta $(20 \%)$ ja kivennäistä $(5 \%)$. Toinen koeryhmä sai vapaasti väkirehuseosta, jossa oli kypsennettyä ohraa (75\%), rypsipuristetta (20\%) ja kivennäistä (5\%). Koeryhmän 2 saamaa ohraa oli kypsennetty litistyksen jälkeen 75 minuutin ajan vesihöyryssä, jonka lämpötila oli 160-180 ${ }^{\circ} \mathrm{C}$. Kokeen aikana vasikat juotettiin 3 kertaa päivässä. Juomarehujauhetta (StarttiTalous) annosteltiin kahteen vesilitraan $250 \mathrm{~g} /$ vasikka/juottokerta, jolloin vasikka sai päivässä enimmillään 750 g juomarehujauhetta. Väkirehun ja juomarehun lisäksi vasikoilla oli kokeen ajan vapaasti tarjolla nurmisäilörehua ja vettä. Vasikat juotettiin kolme kertaa päivässä kuuden viikon ajan eli 8 viikon ikään saakka. Tällöin aloitettiin juotolta vieroitus, joka tapahtui siten, että 8 viikon iässä jätettiin yksi juottokerta pois, ja eläimiä juotettiin viikon ajan kaksi kertaa päivässä. Tämän jälkeen päivittäisten juottokertojen määrä vähennettiin yhteen viikon ajaksi, ja juotto lopetettiin kokonaan ja koe päättyi, kun vasikat olivat 10 viikon ikäisiä.

Vasikoiden rehujen syönnissä tai ravintoaineiden saannissa ei ollut tilastollisesti merkitseviä eroja koko kokeen ajalle (vasikoiden ikä 2-10 viikkoa) laskettuna. Kypsennettyä ohraa saaneet vasikat söivät enemmän väkirehua kuuden ensimmäisen ruokintaviikon aikana verrattuna kypsentämätöntä ohraa saaneisiin vasikoihin $(0,39$ vs. $0,20 \mathrm{~kg} \mathrm{ka} / \mathrm{pv}, \mathrm{P}<0,05)$. Suuremmasta väkirehun syönnistä johtuen myös kokonaiskuiva-aineen syönti vaikutti tällöin olevan suurempi kypsennettyä ohraa saaneilla vasikoilla $(1,14$ vs. $0,96 \mathrm{~kg} \mathrm{ka} / \mathrm{pv}, \mathrm{P}<0.1)$. Ohran kypsentäminen ei vaikuttanut tilastollisesti merkitsevästi vasikoiden kasvuun koko kokeen ajalta mitattuna (päiväkasvu keskimäärin 618 g/pv). Päiväkasvuissa oli kuitenkin eroa kokeen alussa. Kypsennettyä ohraa syöneet vasikat kasvoivat nopeammin 28 viikon iässä verrattuna kypsentämätöntä ohraa syöneisiin vasikoihin (621 vs. $471 \mathrm{~g} / \mathrm{pv}, \mathrm{P}<0,05)$. Ryhmien välinen ero elopainon kehityksessä kuitenkin tasoittui kahden viimeisen koeviikon aikana.

Asiasanat: vasikat, ruokinta, väkirehut, ohra, höyrykypsennys 


\section{Johdanto}

Vastasyntyneen vasikan ruuansulatus muistuttaa yksimahaisten ruuansulatusta. Ruuansulatuksen keskuksena toimii juoksutusmaha. Vasikan etumahat kehittyvät märehtijälle tyypillisiksi, ja sen aineenvaihdunta sopeutuu käyttämään uudenlaisia ravintoaineita 3-8 elinviikolla. Tyypilliset etumahojen liikkeet kehittyvät 6-8 viikon ikään mennessä ja pötsin pieneliöstö vakiintuu 10-12 viikon iässä (Härtel 2003). Pötsi-verkkomahan osuus naudan mahoista on vastasyntyneellä vasikalla $25-35$ prosenttia ja aikuisella naudalla 62-80 prosenttia (Van Soest 1994).

Kuivien rehujen syöminen nopeuttaa etumahojen kasvua ja märehtijäksi kehittymistä, joten vasikalle tulee tarjota juomarehun ohella väkirehua ja karkearehua (Barmore 1994). Viljan tärkkelyksen hajotessa pötsissä siitä muodostuu haihtuvia rasvahappoja, jotka vaikuttavat vasikan etumahojen limakalvojen kehitykseen. Erityisesti pötsin seinämän kehittyminen vaatii haihtuvien rasvahappojen ärsytystä (Van Soest 1994).

Viljan prosessoinnilla pyritään muun muassa parantamaan rehun sulavuutta (Tait ja Beames 1988). Ohran tärkkelyksen kokonaissulavuus on jo yli 95 prosenttia, mikäli jyvät on jauhettu tai litistetty (Beauchemin 2001). Ohraa voidaan prosessoida veden ja lämmön avulla siten, että ohran sisältämät tärkkelysjyväset turpoavat ja tärkkelys liisteröityy (Hunt 1996). Ohran tärkkelys liisteröityy 58$64{ }^{\circ} \mathrm{C}$ lämpötilassa (Armstrong 1972), kun sitä kuumennetaan noin 10 minuutin ajan (Robin Manelius, MTT, 24.4.2006, suullinen tiedonanto). Prestløkkenin (1999) tutkimuksessa ohran expanderointi pienensi kuiva-aineen pötsihajoavuutta. Tämä oli tutkijan mukaan yllättävää, koska yleensä tärkkelyksen liisteröityminen tekee tärkkelyksestä liukoisempaa ja alttiimpaa ruuansulatusentsyymeille. Eräs mahdollinen selitys on, että expanderoinnissa paine ja kuumuus muuttavat tärkkelyksen ja valkuaisen rakennetta taikinamaiseksi, mikä saattaa pienentää pötsihajoavuutta. Grimson ym. (1987) ja Mathison ym. (1991) eivät havainneet ohran höyrykäsittelyn lisäävän nautojen kasvua tai rehun hyväksikäyttöä. Suomessa lypsylehmillä tehdyssä tutkimuksessa ohran höyrykäsittely ei lisännyt maitotuotosta tai rehun syöntiä verrattuna käsittelemättömään ohraan (Khalili ym. 2001). Höyrykäsittelystä voi mahdollisesti olla hyötyä, mikäli se vähentää hienojakoisen jauhon määrää verrattuna kuivana prosessoituun ohraan (Hunt 1996). Tässä raportoitavalla kokeella haluttiin selvittää viljan kypsentämisen vaikutus pikkuvasikoiden kasvuun ja rehun syöntiin juottokauden aikana.

\section{Aineisto ja menetelmät}

Vasikoiden juottokoe suoritettiin Maa- ja elintarviketalouden tutkimuskeskuksella (MTT) Ruukissa 12 maitorotuisella sonnivasikalla. Koevasikat kerättiin paikallisilta lypsykarjatiloilta ternivasikoina (eläinten ikä 1-2 viikkoa). Vasikoiden keräilystä vastasi A-Tuottajat Oy. Juottokoe alkoi syyskuussa 2005 ja päättyi marraskuussa 2005. Vasikat arvottiin välittömästi MTT:lle tulon jälkeen täysin satunnaisesti kahteen ruokintaryhmään. Molempiin ruokintaryhmiin tuli tällöin 6 vasikkaa. Eläimet sijoitettiin kokeen ajaksi yksilökarsinoihin $(120 \mathrm{~cm} * 120 \mathrm{~cm})$, joissa rehujen syönti mitattiin yksilöllisesti päivittäin.

Ruokinnat:

1. Ryhmä sai vapaasti väkirehuseosta, jossa oli ohraa (75\%), rypsipuristetta (20\%) ja kivennäistä (5\%). Ohra oli kypsentämätöntä litistettyä ohraa.

2. Ryhmä sai vapaasti väkirehuseosta, jossa oli ohraa (75\%), rypsipuristetta (20\%) ja kivennäistä (5\%). Ohra oli kypsennettyä litistettyä ohraa.

Ryhmän 2 saamaa ohraa oli kypsennetty litistyksen jälkeen 75 minuutin ajan vesihöyryssä, jonka lämpötila oli $160-180^{\circ} \mathrm{C}$. Litistetyn ohran lämpötila oli prosessin loppuvaiheessa $63^{\circ} \mathrm{C}$. Kokeessa käytetty rypsipuriste oli kaupallista Tähkä Rypsimure 150-valmistetta ja kivennäinen Mulli-Melliä.

Ruokintakokeen aikana vasikat juotettiin 3 kertaa päivässä, ja juottoajat olivat klo 6:30, 12:00 ja 18:00. Juomarehujauhetta (StarttiTalous) annosteltiin kahteen vesilitraan $250 \mathrm{~g} /$ vasikka/juottokerta, jolloin vasikka sai päivässä enimmillään $750 \mathrm{~g}$ juomarehujauhetta. Tuttiämpäreistä juotettavan juomarehun lämpötila oli $38^{\circ} \mathrm{C}$. Vasikat juotettiin kolme kertaa päivässä kuuden viikon ajan eli kahdeksan viikon ikään saakka. Tällöin aloitettiin juotolta vieroitus, joka tapahtui siten, että kahdeksan viikon iässä jätettiin yksi juottokerta pois, ja eläimiä juotettiin viikon ajan kaksi kertaa päivässä. Tämän jälkeen päivittäisten juottokertojen määrä vähennettiin yhteen viikon ajaksi, ja juotto lopetettiin kokonaan ja koe päättyi, kun vasikat olivat 10 viikon ikäisiä. Väkirehun lisäksi vasikoilla oli kokeen ajan vapaasti tarjolla nurmisäilörehua ja vettä. 
Vasikat punnittiin kokeen aikana kahden viikon välein. Kokeen alussa ja lopussa vasikat punnittiin kahtena peräkkäisenä päivänä ja punnitustuloksena käytettiin kahden punnituskerran keskiarvoa. Rehuista kerättiin niiden päivittäisten punnitusten yhteydessä keruunäytteet, jotka yhdistettiin edustaviksi kokoomanäytteiksi. Nurmisäilörehusta määritettiin kuiva-aine, tuhka, NDF-kuitu, raakavalkuainen, raakarasva ja D-arvo (sulavan orgaanisen aineen pitoisuus kuiva-aineessa) sekä käymislaatu (pH, kokonaistyppi, liukoinen typpi, ammoniumtyppi, haihtuvat rasvahapot ja maito- sekä muurahaishappo) ja syönti-indeksi. Väkirehuista ja juomarehusta määritettiin kuiva-aine, tuhka, NDF-kuitu, raakavalkuainen, raakarasva. Rehujen primäärinen kuiva-aine määritettiin lämpökaapissa $\left(105^{\circ} \mathrm{C}, 20 \mathrm{~h}\right)$. Säilörehun kuiva-aine korjattiin haihtuvien yhdisteiden (maitohappo, haihtuvat rasvahapot ja ammoniakki) osalta Huidan ym. (1986) mukaan. Tuhkapitoisuus määritettiin polttamalla näytettä $\left(600{ }^{\circ} \mathrm{C}, 18 \mathrm{~h}\right)$. Neutraalidetergenttikuitu (NDF) analysoitiin Van Soestin ym. (1991) mukaan. Raakavalkuainen määritettiin Dumas -tyypin typpianalysaattorilla (Leco FP-428 N Analyser, Leco Corporation, St. Joseph, MO, USA) ja rasva AOAC:n (1990) (procedure 920.39) mukaan. Säilörehusta käymislaatu määritettiin Valio Oy:ssä käytössä olevalla puristenestetitraukseen pohjautuvalla laatumäärityksellä (Moisio ja Heikonen 1989). Säilörehun D-arvo määritettiin Nousiainen ym. (2003) kuvaamalla tavalla ja syöntiindeksi Huhtasen ym. (2007) mukaisesti.

Väkirehujen muuntokelpoinen energia (ME) laskettiin MAFFin $(1975,1981,1984)$ ja Schiemannin ym. (1972) mukaan. Säilörehun ME-arvo laskettiin rehun sisältämän sulavan orgaanisen aineen perusteella kertomalla D-arvo 16:1la (MAFF 1975). Väkirehujen sulavuuskertoimet laskettiin MTT:n rehutaulukoiden arvojen perusteella (MTT 2006). Rehuyksikköarvot (ry) laskettiin jakamalla ME-arvo 11,7:11ä (MTT 2006). Rehujen valkuaisarvot laskettiin Suomen olosuhteisiin muunnetun pohjoismaisen valkuaisarvojärjestelmän mukaan ohutsuolesta imeytyvinä aminohappoina (OIV) ja pötsin valkuaistaseena (PVT) (MTT 2006). Ravintoaineiden saanti laskettiin kertomalla syötyjen rehujen määrä niitten ravintoainepitoisuuksilla.

Vasikoiden päivittäiseen terveysseurantaan kuuluivat sonnan silmämääräinen määritys, puhaltuminen, karvanlähtö, liikkumisongelmat: esim. huojuminen, liikekoordinaatio-ongelmat, ylösnousuvaikeudet sekä mahdolliset muut terveysongelmat: (yskä, hengitystietulehdus, napatulehdus, ym.).

Vasikoiden punnitus- ja rehun syöntitulosten sekä rehuanalyysitulosten perusteella laskettiin eläinten päiväkasvu, väkirehun, juomarehun ja säilörehun syönti sekä energian saanti juottokauden aikana. Lisäksi laskettiin rehuhyötysuhde eli kasvua kohti kulutettu rehu- ja energiamäärä. Kasvu- ja teurastulosten tilastolliseen käsittelyyn käytettiin SAS-ohjelmiston GLM-proseduuria. Koekäsittelyiden erot testattiin varianssianalyysillä. Keskiarvojen tilastolliset merkitsevyydet todettiin niin että $\mathrm{P}<0,001 * * *$ oli erittäin merkitsevä ero, $\mathrm{P}<0,01 * *$ oli hyvin merkitsevä ero, $\mathrm{P}<0,05 *$ oli merkitsevä ero ja $\mathrm{P}<0,10$ o oli suuntaa-antava ero.

Kokeen aikana jouduttiin lopettamaan yksi vasikka, jolla oli juoksutusmahan laajentuma. Kyseisen eläimen tuloksia ei käytetty laskennassa. Vasikka oli ryhmässä, joka sai kypsennettyä ohraa. Ei ole syytä olettaa, että sairastuminen olisi johtunut koeruokinnasta.

\section{Tulokset ja tulosten tarkastelu}

Kypsennetyn ja kypsentämättömän ohran kemiallisessa koostumuksessa ja rehuarvoissa ei ollut suuria eroja (Taulukko 1). Ohra oli rehuarvoltaan hyvää. Sen rehuyksikköarvo oli 1,13 ry/kg ka ja raakavalkuaispitoisuus oli kypsentämättömässä 132 ja kypsennetyssä $131 \mathrm{~g} / \mathrm{kg}$ ka. Kokeessa käytetty säilörehu oli säilönnälliseltä laadultaan hyvää. Säilörehun D-arvo (664 g/kg ka) oli hieman suositeltua pienempi. Vasikoiden rehujen syönnissä tai ravintoaineiden saannissa ei ollut tilastollisesti merkitseviä eroja koko kokeen ajalta laskettuna (vasikoiden ikä 2-10 viikkoa) (Taulukko 2). Kypsennettyä ohraa saaneet vasikat söivät enemmän väkirehua kuuden ensimmäisen ruokintaviikon aikana verrattuna kypsentämätöntä ohraa saaneisiin vasikoihin $(0,39$ vs. $0,20 \mathrm{~kg} \mathrm{ka} / \mathrm{pv}, \mathrm{P}<0,05)$. Suuremmasta väkirehun syönnistä johtuen myös kokonaiskuiva-aineen syönti vaikutti suuremmalta kypsennettyä ohraa saaneilla vasikoilla kyseisenä ajanjaksona ( 1,14 vs. $0,96 \mathrm{~kg} \mathrm{ka} / \mathrm{pv}, \mathrm{P}<0.1)$.

Ohran kypsentäminen näytti myös lisäävän vasikoiden ravintoaineiden saantia kuuden ensimmäisen ruokintaviikon aikana verrattuna kypsentämättömään ohraan (Taulukko 2). Syynä ravintoaineiden saannin lisääntymiseen oli lisääntynyt kuiva-aineen syöntimäärä. Juotolta vieroituksen aikana (ruokintaviikoilla 7-8) rehun syönnissä ja ravintoaineiden saannissa ei ollut merkitseviä eroja ruokintaryhmien välillä. 
Taulukko 1. Rehujen kemiallinen koostumus, rehuarvot ja säilörehun säilönnällinen laatu.

\begin{tabular}{|c|c|c|c|c|c|}
\hline & \multicolumn{2}{|c|}{ Ohra } & \multirow[t]{2}{*}{ Rypsi } & \multirow[t]{2}{*}{ Juomarehu } & \multirow[t]{2}{*}{ Säilörehu } \\
\hline & Kypsentämätön & Kypsennetty & & & \\
\hline Kuiva-aine, $\mathrm{g} / \mathrm{kg}$ & 861 & 858 & 885 & 966 & 226 \\
\hline \multicolumn{6}{|l|}{ Kuiva-aineessa, g/kg ka } \\
\hline tuhka & 23 & 23 & 86 & 76 & 63 \\
\hline raakavalkuainen & 132 & 131 & 332 & 218 & 160 \\
\hline raakarasva & 22 & 23 & 50 & 8 & 37 \\
\hline neutraalidetergenttikuitu & 208 & 202 & 266 & 10 & 580 \\
\hline Ry-arvo, Ry/kg ka & 1,13 & 1,13 & 1,09 & 1,35 & 0,90 \\
\hline $\mathrm{OIV}, \mathrm{g} / \mathrm{kg} \mathrm{ka}$ & 106 & 107 & 150 & 190 & 82 \\
\hline D-arvo, $\mathrm{g} / \mathrm{kg} \mathrm{ka}$ & & & & & 664 \\
\hline Syönti-indeksi & & & & & 95 \\
\hline \multicolumn{6}{|l|}{ Säilörehun säilönnällinen laatu } \\
\hline $\mathrm{pH}$ & & & & & 3,83 \\
\hline Haihtuvat rasvahapot (g/kg ka) & & & & & 12 \\
\hline Maito- ja muurahaishappo (g/kg ka) & & & & & 46 \\
\hline Sokerit (g/kg ka) & & & & & 84 \\
\hline \multicolumn{6}{|l|}{ Kokonaistypestä, g/kg N } \\
\hline Ammonium typpi & & & & & 70 \\
\hline Liukoinen typpi & & & & & 560 \\
\hline
\end{tabular}

Taulukko 2. Vasikoiden rehun syönti ja ravintoaineiden saanti.

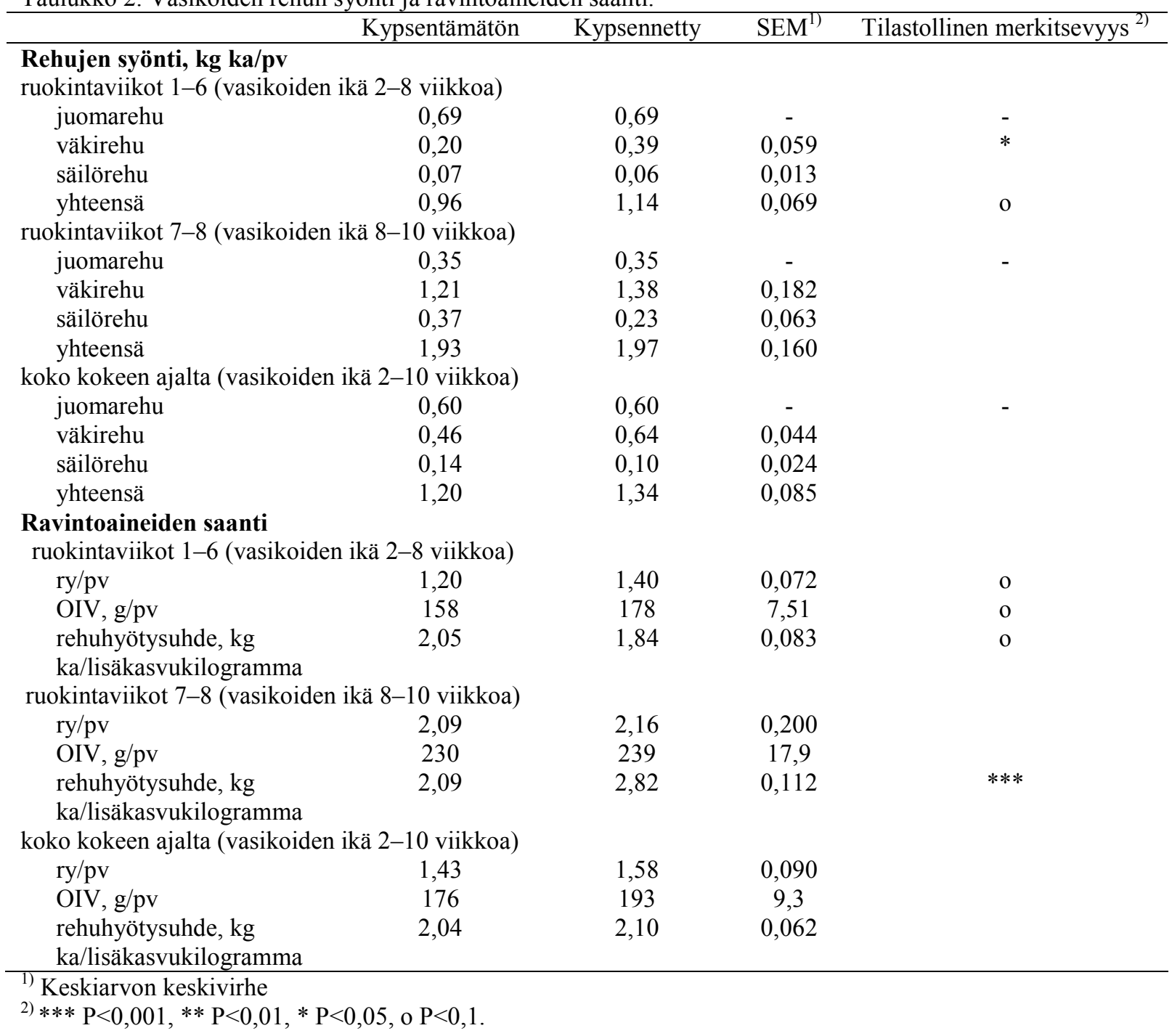


Kypsennettyä ohraa saaneiden vasikoiden kokonaiskuiva-aineen syönti lisääntyi 2-4 viikon iässä nopeammin kuin kypsentämätöntä ohraa syöneillä vasikoilla (Kuva 1.) Kypsentämätöntä ohraa saaneet vasikat taas lisäsivät rehun syöntiä 6-8 viikon iässä siten että kokeen lopussa, kun vasikat olivat kymmenen viikon ikäisiä, rehujen kokonaissyönti oli yhtä suurta molemmissa ryhmissä.

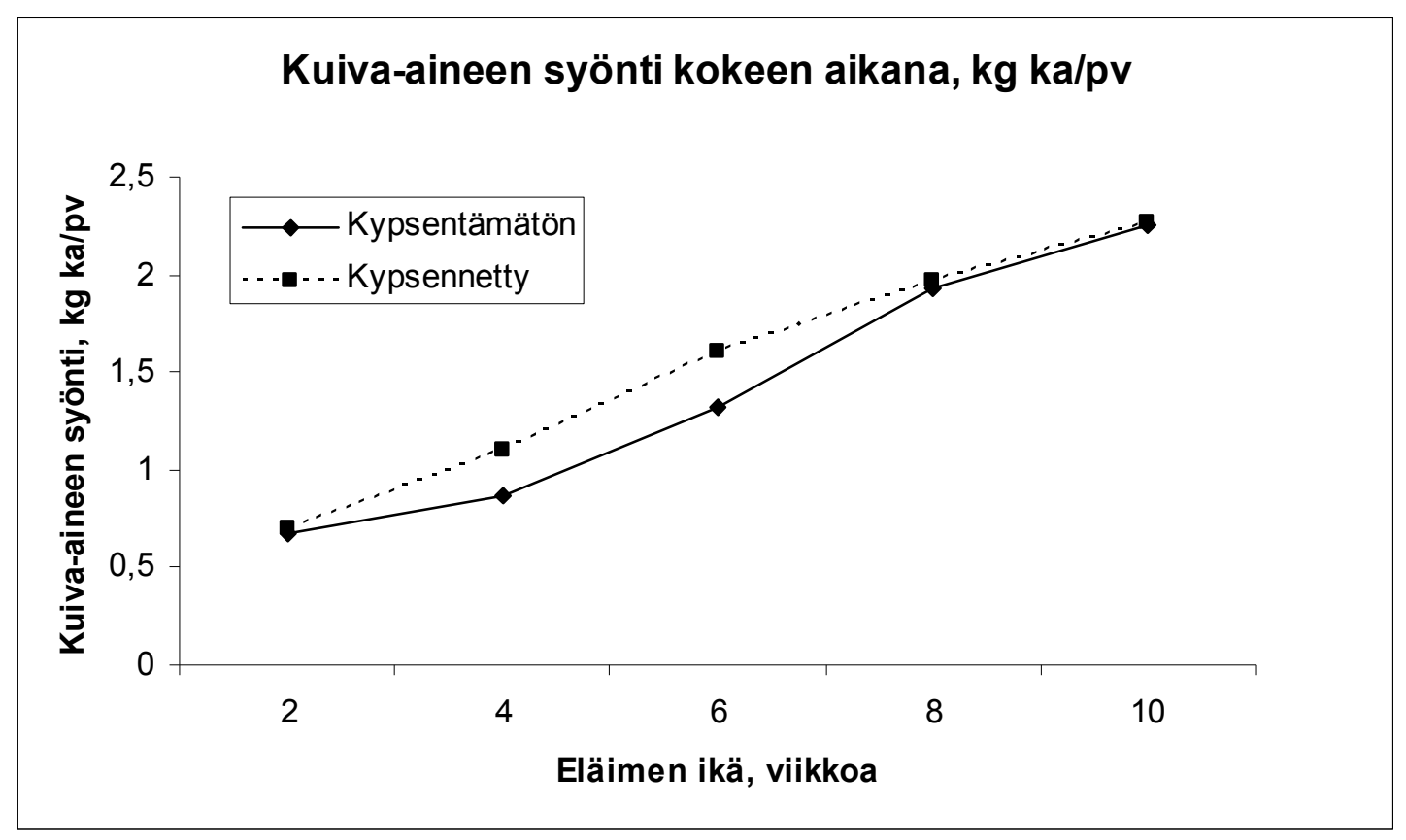

Kuva 1. Ohran kypsentämisen vaikutus kokonaiskuiva-aineen syöntiin pikkuvasikoilla. Vasikat olivat ruokintakokeen alkaessa keskimäärin 14 päivän ikäisiä.

Ohran kypsentäminen ei vaikuttanut tilastollisesti merkitsevästi vasikoiden kasvuun koko kokeen ajalta mitattuna, vaikka kypsennettyä ohraa saaneiden vasikoiden päiväkasvut olivat numeerisesti hieman suurempia kuin kypsentämätöntä ohraa syöneet vasikoiden (Taulukko 3). Päiväkasvuissa oli kuitenkin eroa kokeen alussa. Kypsennettyä ohraa syöneet vasikat kasvoivat nopeammin $2-8$ viikon iässä verrattuna kypsentämätöntä ohraa syöneisiin vasikoihin (621 vs. $471 \mathrm{~g} / \mathrm{pv}, \mathrm{P}<0,05)$, mutta ryhmien välinen ero elopainon kehityksessä tasoittui kahden viimeisen viikon aikana. Kypsennettyä ohraa syöneiden vasikoiden keskimääräinen elopaino oli kokeen alussa hieman pienempi kuin kypsentämätöntä ohraa syöneiden vasikoiden (45 vs. $48 \mathrm{~kg}$ ). Kokeen lopussa molemmissa ryhmissä vasikoiden keskimääräinen elopaino oli $82 \mathrm{~kg}$. Kypsennettyä ohraa syöneiden vasikoiden päiväkasvu oli keskimäärin 643 ja kypsentämätöntä ohraa syöneiden vasikoiden päiväkasvu oli 592 grammaa päivässä. Päiväkasvut olivat tässä tutkimuksessa samalla tasolla kuin aikaisemmissa rajoitetulla juotolla toteutetuissa tutkimuksissa (Huuskonen ym. 2005a,b).

Taulukko 3. Vasikoiden kasvutulokset.

\begin{tabular}{ccccc}
\hline & Kypsentämätön & Kypsennetty & SEM $^{1)}$ & Tilastollinen merkitsevyys $^{2)}$ \\
\hline Elopaino, kg & & & & \\
2 viikon iässä & 48 & 45 & 3,8 & \\
8 viikon iässä & 68 & 72 & 5,3 & \\
10 viikon iässä & 82 & 82 & 6,1 & $*$ \\
Päiväkasvu, g/pv & & & & \multirow{2}{*}{} \\
2-8 viikon iässä & 471 & 621 & 42,3 & 81,3 \\
$8-10$ viikon iässä & 939 & 707 & 48,3 & \\
2-10 viikon iässä & 592 & 643 & & \\
\hline
\end{tabular}

1) Keskiarvon keskivirhe

2) $* * * \mathrm{P}<0,001, * * \mathrm{P}<0,01, * \mathrm{P}<0,05$, o $\mathrm{P}<0,1$. 
Kypsennettyä ohraa syöneiden vasikoiden elopaino lisääntyi hieman kontrolliryhmää nopeammin kokeen alkupuolella (Kuva 2), mutta ruokintaryhmien välinen ero elopainon kehityksessä kuitenkin tasoittui, kun vasikat vieroitettiin maitojuotolta 8-10 viikon iässä. Kypsentämätöntä ohraa syöneet vasikat kompensoivat alun hitaampaa kasvua kokeen kahden viimeisen viikon aikana, jolloin niiden kasvu oli nopeampaa kuin kypsennettyä ohraa syöneiden vasikoiden. Vieroituksen aikana kypsennettyä ohraa syöneiden vasikoiden keskimääräinen päiväkasvu oli 707 grammaa ja kypsentämätöntä ohraa syöneiden vasikoiden päiväkasvu oli 939 grammaa. Kahden viimeisen koeviikon aikana kontrolliryhmän rehuhyötysuhde (kuiva-aineen syönti suhteessa lisäkasvuun) oli parempi kuin kypsennettyä ohraa saaneilla vasikoilla ( 2,09 vs. $2,82 \mathrm{~kg} \mathrm{ka} / \mathrm{lisäkasvu-kg,} \mathrm{P}<0,001)$ (Taulukko 2$)$.

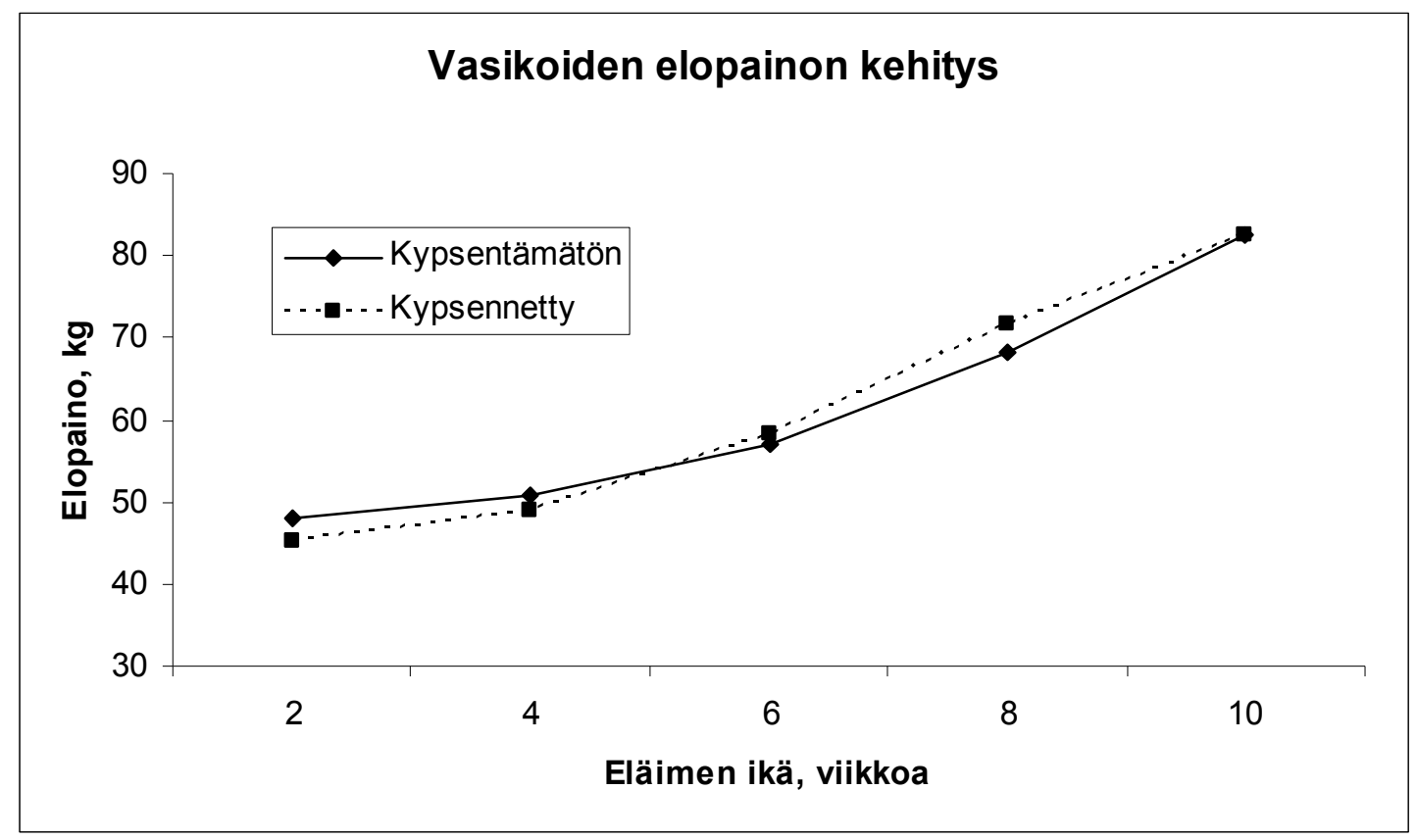

Kuva 2. Vasikoiden elopainon kehitys. Vasikat olivat kokeen alkaessa keskimäärin 14 päivän ikäisiä.

\section{Yhteenveto ja johtopäätökset}

Ohran kypsentäminen ei vaikuttanut 2-10 viikon ikäisten pikkuvasikoiden rehun syöntiin, ravintoaineiden saantiin tai kasvutuloksiin. Kypsentäminen lisäsi vasikoiden rehun syöntiä ja päiväkasvua toisesta elinviikosta kahdeksanteen elinviikkoon asti, mutta ero tasoittui 8-10 viikon iässä, jolloin kypsentämätöntä ohraa syöneet vasikat lisäsivät syöntiä ja päiväkasvua.

\section{Kirjallisuus}

AOAC 1990. Official methods of analysis. 15th edition. Associations of Official Analytical Chemists, Arlington, VA. $1298 \mathrm{~s}$.

Armstrong, D.G. 1972. Developments in cereal processing - ruminants. Teoksessa: Cereal processing and digestion. The U.S. Feed Grains Council. Lontoo. s. 9-37.

Barmore, J.A. 1994. New calf management practices enhance production efficiency. Feedstuffs 66:12-14.

Beauchemin, K.A., Yang, W.Z. \& Rode, L.M. 2001. Effects of barley grain processing on the site and extent of digestion of beef feedlot finishing diets. J. Anim. Sci. 79:1925-1936.

Grimson, R.E., Weisenburger, R.D., Basarab, J.A. \& Stilborn, R.P. 1987. Effects of barley volume- weight and processing method on feedlot performance of finishing steers. Can. J. Anim. Sci. 67:43-53.

Huhtanen, P., Rinne, M. \& Nousiainen, J. 2007. Evaluation of the factors affecting silage intake of dairy cows: a revision of the relative silage dry-matter intake index. Animal 1: 758-770.

Huida, L., Väätäinen, H. \& Lampila, M. 1986. Comparison of dry matter contents in grass silages as determined by oven drying and gas chromatographic water analysis. Ann. Agr. Fenn. 25: 215-230.

Hunt, C.W. 1996. Factors affecting the feeding quality of barley for ruminants. Anim. Feed Sci. Technol. 62:3748. 
Huuskonen, A., Khalili, H., Kiljala, J., Joki-Tokola, E. \& Nousiainen, J. 2005a. Effects of vegetable fats versus lard in milk replacers on feed intake, digestibility, and growth in Finnish Ayrshire bull calves. J. Dairy Sci. 88: 3575-3581.

Huuskonen, A., Pihamaa, P. \& Khalili, H. 2005b. Juottomäärän vaikutus vasikoiden tuotantotuloksiin ja tuotannon talouteen kolmivaihekasvatuksessa. Teoksessa: Pihamaa, P. \& Huuskonen, A.(toim.). Uusien naudanlihantuotantomenetelmien talous. Maa- ja elintarviketalous 75. Maa- ja elintarviketalouden tutkimuskeskus. s.1736.

Härtel, H. 2003. Vasikan ruoansulatuksen kehitys. Teoksessa: Vasikkaopas. Helsinki: Valio Oy. s. 16-19.

Khalili, H., Sairanen, A., Hissa, K. \& Huhtanen, P. 2001. Effects of type and treatment of grain and protein source on dairy cow performance. Anim. Sci. 72:573-584.

MAFF 1975. Energy allowances and feeding systems for ruminants. Technical Bulletin 33. London: Her Majesty's Stationery Office. $79 \mathrm{~s}$.

MAFF 1981. Animal Science 1979. ADAS Agricultural Science Service, Research and Developments Reports. Reference book 254. London: Her Majesty's Stationery Office. 103 s.

MAFF 1984. Energy Allowances and Feeding Systems for Ruminants. Reference book 433. London: Her Majesty's Stationary Office. $85 \mathrm{~s}$.

Mathison, G.W., Hironaka, R., Kerrigan, B.K., Vlach, I., Milligan, L.P. \& Weisenburger, R.D. 1991. Rate of starch degradation, apparent digestibility and rate and efficiency of steer gain as influenced by barley grain volume-weight and processing method. Can. J. Anim. Sci. 71:867-878.

Moisio, T. \& Heikonen, M. 1989. A titration method for silage assessment. Anim. Feed Sci. Technol. 22: 341353.

MTT 2006. Rehutaulukot ja ruokintasuositukset. Verkkodokumentti. Jokioinen: MTT. Julkaistu: 14.2.2006, Viitattu: 1.11.2007. Saatavilla internetistä: http://www.agronet.fi/rehutaulukot/. URN:NBN:fi-fe20041449.

Nousiainen, J., Rinne, M., Hellämäki, M. \& Huhtanen, P. 2003. Prediction of the digestibility of the primary growth of grass silages harvested at different stages of maturity from chemical composition and pepsin-cellulase solubility. Anim. Feed Sci. Technol. 103: 97-111.

Prestløkken, E. 1999. In situ ruminal degradation and intestinal digestibility of dry matter and protein in expanded feedstuffs. Anim. Feed Sci. Technol. 77:1-23.

Schiemann, R., Nehring, K., Hoffmann, L., Jentsch, W. \& Chudy, A. 1972. Energetische Futterbewertung und Energienormen. VEB Deutcher Landwirtschafsverlag Berlin, Germany. 344 s.

Tait, R.M. \& Beames, R.M. 1988. Processing and preservation of Cereals and Protein Concentrates. Teoksessa: Ørskov (toim.). World animal science, B4: Feed science. Amsterdam: Elsevier. s.151-175.

Van Soest, P. J. 1994. Nutritional ecology of the ruminant. Cornell university press. New York. 476 p.

Van Soest, P.J., Robertson, J.B., Lewis, B.A. 1991. Methods for dietary fibre, neutral detergent fibre and nonstarch polysaccharides in relation to animal nutrition. J. Dairy Sci. 74: 3583-3552. 